九州大学学術情報リポジトリ

Kyushu University Institutional Repository

\title{
Linear and Circular Conformation of Pock- Forming Plasmid pSAL of Thiostrepton-Producing Streptomyces azureus ATCC 14921
}

Ogata, Se iya

Microbial Genetics Division, Institute of Genetic Resources, Faculty of Agriculture, Kyushu University

Koyama-Miyoshi, Yuko

Laboratory of Applied Microbiology, Department of Agricultural Chemistry, Kyushu University

Hayashida, Shinsaku

Laboratory of Applied Microbiology, Department of Agricultural Chemistry, Kyushu University

https://doi.org/10.5109/23882

出版情報 : 九州大学大学院農学研究院紀要. 32 (3/4), pp. 273-281，1988-03. Kyushu University バージョン：

権利関係: 


\title{
Linear and Circular Conformation of Pock-Forming Plasmid pSAl of Thiostrepton-Producing Streptomyces azureus ATCC 14921
}

\author{
Seiya Ogata' *, Yuko Koyama-Miyoshi ${ }^{2}$ and Shinsaku Hayashida ${ }^{2}$ \\ Microbial Genetics Division, Institute of Genetic Resources' \\ Laboratory of Applied Microbiology, Department of Agricultural \\ Chemistry $^{2}$, Kyushu University, 46, Fukuoka 812, Japan \\ (Received December 7, 1987)
}

\begin{abstract}
A wild-type strain (ATCC 14921) of thiostrepton-producing Streptomyces azureus is a pockforming strain and harbors a plasmidpSAl.PlasmidpSAl was found to be in a linear form in mycelia grown in abnormal plate culture with overlapping phage plaque-like pocks, but in a closed-circular form in liquid culture or in normal plate culture with no pock. The DNAs of both forms elicited conjugative pocks on sensitive strain PKC. The linear form of pSAl was considered to be converted from the closed-circular form via an intermediate, an open-circular form. The copy size of closed-circular forms was one or less per host genome. The number of linear forms in one cell was estimated to be five or more. No plasmid was isolated from a mutant strain PKC, which lost the pock-forming activity.
\end{abstract}

\section{INTRODUCTION}

Many of the plasmids isolated from the Streptomyces species are phenotypically detectable according to their ability to elicit zones of growth inhibition, or "pocks", when the plasmid-carrying strains are grown in contact with plasmid-free strains on agar media. Plasmids SCP2 and SCP2* of Streptomyces coelicolor A3 (2) (Bibb et al., 1977 ; Bibb and Hopwood, 1981) and several other Streptomyces' plasmids (Akagawa et al., 1984; Kobayashi et al., 1984; Manis and Highlander, 1982 ; Murakami et al., 1983 ; Omer and Cohen, 1985) are such conjugative plasmids and elicit pocks.

Thiostrepton-producing Streptomyces azureus ATCC 14921 formed a unique lawn with phage plaque-like pocks on agar media (Ogata et al., 1981). These pocks appeared spontaneously during the growth of the organisms and increased in number in subculturing. This appearance brings about an abnormal growth of cultures, a diminished production of thiostrepton and difficulty for stock cultures (Ogate et al., 1981). S. azureus also formed pocks (named conjugative pocks) similar to those of S. coelicolor and others on a sensitive strain PKC (Miyoshi et al., 1986). A low-copy number plasmid $\mathrm{pSAl}$, which elicited pocks, was isolated from this wild-type strain. In our previous paper (Ogate et al., 1983), pSAl was found to be a linear plasmid in plate culture with overlapping pocks. This paper describes experiments concerning conversion from the circular to the linear form of $\mathrm{pSAl}$.

\footnotetext{
* Corresponding author
} 
MATERIALS AND METHOD

\section{Strains}

Streptomyces azureus wild-type strain ATCC 14921 was used throughout this work. A pock-cured mutant PKC, previously called AF-6 (Ogate et al., 1983), was obtained from wild-type strain by acriflavin treatment.

\section{M edium}

Rye flakes agar medium (Ogate et al., 1981) was used for plate culture and pock formation. YEME medium supplemented with $34 \%$ sucrose and $5 \mathrm{mM} \mathrm{MgCl}_{2}$ (YEMES) (Bibb et al., 1977) was used as described below.

\section{Plate culture with overlapping pocks}

The plate culture of wild-type strain showed spontaneously developing plaque-like pocks. The pocks increased in number in serial subcultures. The incubation was for 3-5 days at $28^{\circ} \mathrm{C}$.

\section{DNA isolation}

In the case of plate culture, spores of wild-type strain from abnormal slant or of strain PKC were inoculated and grown on cellophane-coated Rye flakes agar for $48 \mathrm{hr}$ at $28^{\circ} \mathrm{C}$. In the case of liquid culture, approximately $10^{7}$ spores $/ \mathrm{ml}$ of each strain were inoculated in YEMES medium and cultivated for 40 to $48 \mathrm{hr}$ at $28^{\circ} \mathrm{C}$ on a rotary shaker (250 rpm).

Two g wet mycelia of each strain from the plate or liquid culture was adapted to DNA preparation. Total DNA and plasmid DNA from each strain were prepared as in Chater et al. (1982).

\section{Estimation of copy numbers of plasmids}

The relative copy numbers of plasmid in wild-type strain were estimated according to Kieser et al. (1982). esis

Digestion of DNA with restriction endonucleases and agarose gel electrophor-

Digestion of DNA with restriction endonuclease EcoRI and agarose gel electrophoresis were carried out according to Maniatis et al. (1982). The molecular weights of DNA fragments were measured with reference to the HindIII digest of phage lambda DNA.

\section{H ybridization}

Hybridization was carried out by the Southern blotting method (Maniatis et al, 1982), as described previously (Ogata et al., 1984).

\section{Transformation}

Protoplasting, regeneration and transformation were as described previously (Ogate et al., 1983, 1985). 


\section{RESULTS AND DISCUSSION}

\section{Morphology of plate culture}

Plate culture of wild-type strain shows spontaneously developing plaque-type pocks, as shown in Fig. 1-b. Pocks in the plate increased in number during serial subcultures. After three or four transplantations, they became overlapping pocks or semiconfluent pocks, as shown in Fig. 1-a.

We could temporarily cure this abnormality by the following treatment. Sores and mycelia of eroded plate were incubated in a liquid medium for more than $24 \mathrm{hr}$ with shaking. After that, growing mycelia were reinoculated on Rye flakes agar. The lawn developed was characterized by a few pocks like that in the plate of Fig. 1-b or occasionally no pocks. However, these cultures again became abnormal by serial subcultures.

Strain PKC, which was selected by acriflavin treatment, has no pocks, as shown in Fig. 1-c.
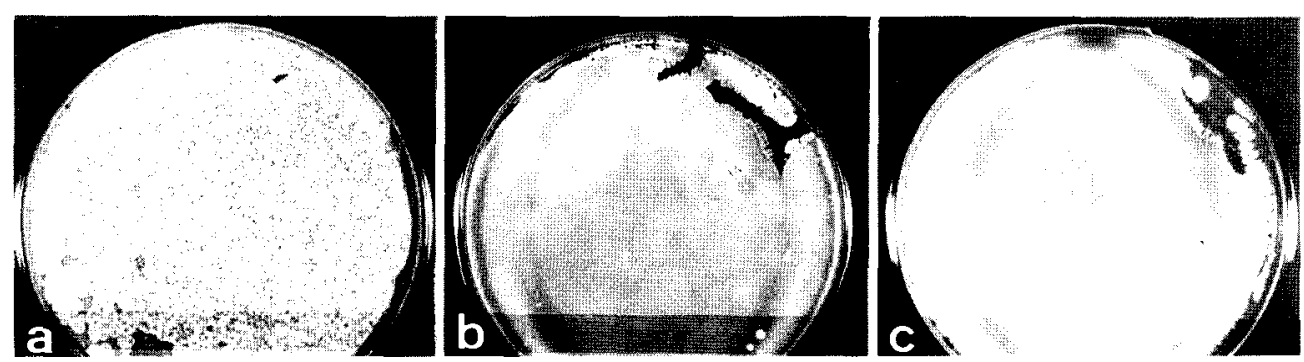

Fig. 1. Photographs of plate cultures of wild-type strain and strain PKC of Streptomyces azureus.

a, wild-type strain with overlapping pocks ; b, wild-type strain with few pocks ; c, strain PKC.

\section{Isolation of plasmid pSAl from mycelia grown in plate culture}

The DNA preparation (cleared lysate) from the mycelia grown in plate culture was subjected to ethidium bromide-caesium chloride $(\mathrm{EtBr} \cdot \mathrm{CsCl})$ density gradient centrifugation. The clear band of plasmid was hardly detected. Therefore, fractions obtained were loaded into the slots of an agarose gel, and Hind111 digest of phage lambda DNA was used as molecular size markers. As shown in Fig. 2, there is a distinct DNA band among bacterial DNA, of which the molecular length is approximately $9.0 \mathrm{~kb}$. This band indicates a linear conformation.

The DNA preparation was next subjected to neutral sucrose density gradient centrifugation. Two DNA bands designated as A and B are observed, as shown in Fig. 3. The molecular lengths of bands A (major) and B (minor) are approximately $9.0 \mathrm{~kb}$ and $14.5 \mathrm{~kb}$, respectively.

Separation and concentration were carried out on these two kinds of DNA. Figure 4 shows an agarose gel electrophoresis for each band DNA. It is confirmed that band $\mathrm{A}$ is about $9.0 \mathrm{~kb}$ and band $\mathrm{B}$ was about $14.5 \mathrm{~kb}$. When each band DNA was applied 


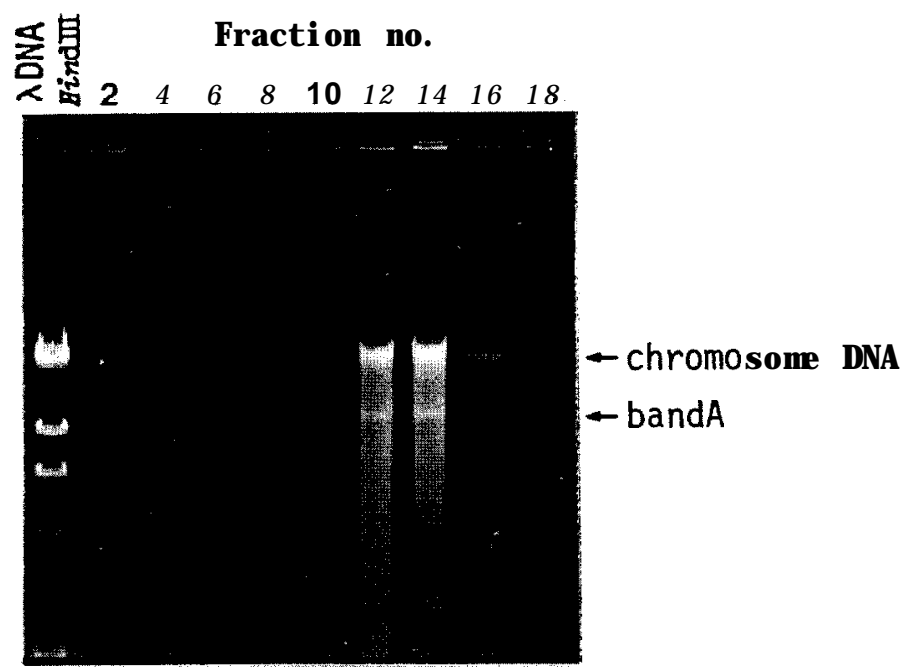

Fig. 2. Agarose gel electrophoresis of fractionated. DNAs from wild-type strain grown in plate culture of Streptomyces azureus after ethidium bromide-caesium chloride centrifugation.

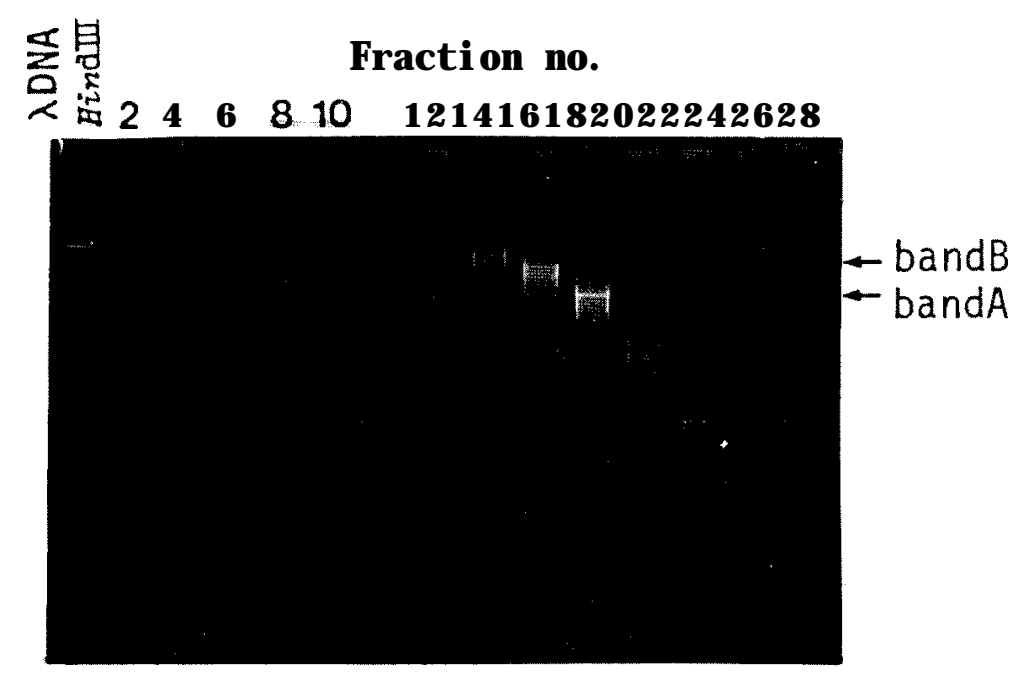

Fig. 3. Agarose gel electrophoresis of fractionated DNAs from wild-type strain grown in plate culture of Streptomyces azureus after sucrose density gradient centrifugation.

to $\mathrm{EtBr}-\mathrm{CsCl}$ density gradient centrifugation, they were distributed at the position for linear conformation during centrifugation. On the other hand, these DNA bands were hardly detectable in the clear lysate from strain PKC. 


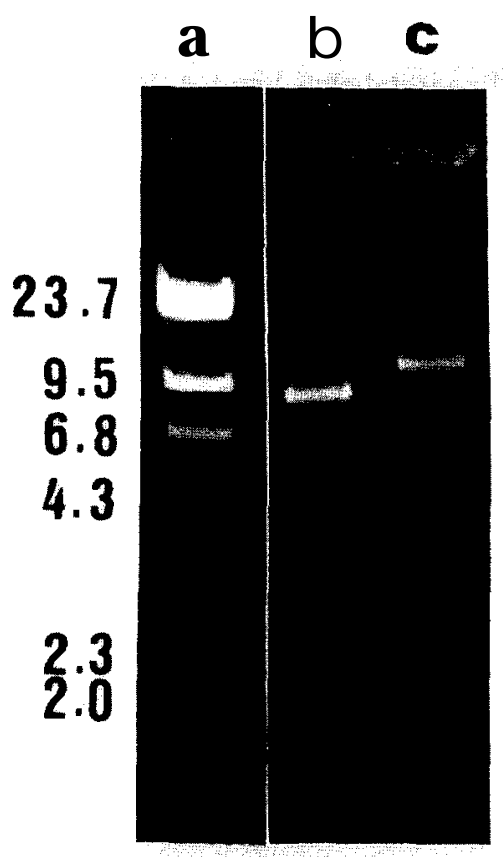

Fig. 4. Agarose gel electrophoresis of band A and band B DNAs from wild-type strain of Streptomyces azureus.

Lane a, phage lambda DNA digested with Hind111 ; lane b, band A ; lane c, band B.

During the purification of the DNAs of two bands with phenol-treatment, EtBr. $\mathrm{CsCl}$ density gradient centrifugation, agarose gel electrophoresis and so on, a part of band B DNA easily changed to band A DNA. This indicates that band B DNA has an open-circular (oc) conformation, which is nicked.

\section{Isolation of plasmid pSAl from mycelia grown in liquid culture}

The same experiments as above were performed on the DNA preparation of the mycelia grown in liquid culture. A samll amount of closed-circular (cc) DNA band designated $\mathrm{C}$ was observed in $\mathrm{EtBr}-\mathrm{CsCl}$ density gradient centrifugation. The molecular length was approximately $7 \mathrm{~kb}$. During the preparation of band C DNA, it sometimes changed to two others having about $9.0 \mathrm{~kb}$ and $14.5 \mathrm{~kb}$. From this result, it is supposed that band C DNA changes to band A DNA via an intermediate, band B DNA.

The relative copy number of plasmidpSAl in the cells grown in liquid culture was estimated to be 0.5 to 1 per host genome throughout the whole growth phase. From this datum, the copy number of the linear forms in one cell grown in plate culture was calculated to be roughly 5 .

The same circular plasmid was also isolated from the mycelia of normal plate culture with no pock or a few pocks like Fig. 1-b. The copy number was less than 0.5 . 
Relationships among band A, band B and band C DNAs

To examine the similarity among bands A, B and CDNAs, Southern blot hybridization was carried out and radiolabeled band A DNA was used as a probe. A high

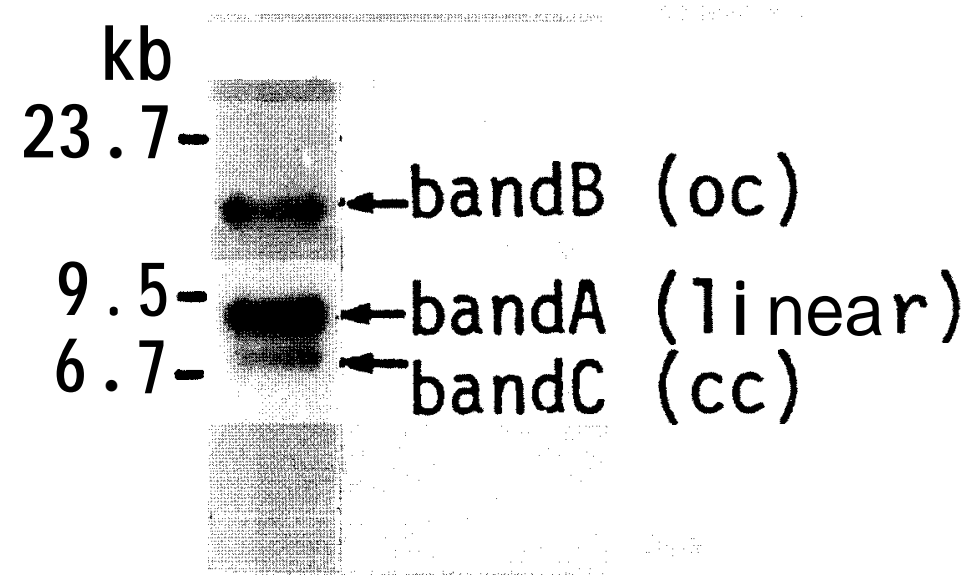

Fig. 5. Southern blot analysis of band A, band B and band C DNAs using band A DNA as a hybridization probe.

The lengths (in $\mathrm{kb}$ ) and positions of HindIII-cleaved lambda DNA markers are indicated.

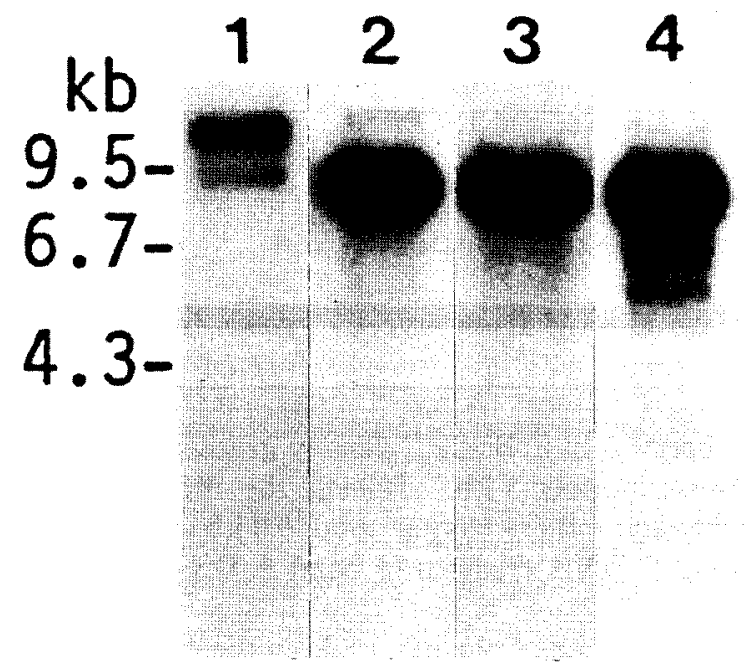

Fig. 6. Southern blot analysis of band A and band B DNAs using band A DNA as a hybridization probe.

Lane 1, band B DNA (with band A DNA) ; lane 2, EcoRI-cleaved band B DNA ; lane 3, band A DNA ; lane 4, Eco RI-cleaved band A DNA'.

The lengths (in $\mathrm{kb}$ ) and position of HindIII-cleaved lambda DNA markers are indicated. 
homology of these three DNAs was determined, as shown in Fig. 5.

To confirm the conversion of band B DNA to band A DNA, band B DNA was digested with restriction endonuclease EcoRI, and the digest was subjected to Southern blot analysis, as described above. Figure 6 shows that EcoRI-digest of band B DNA has the same molecular length (about $9.0 \mathrm{~kb}$ ) as that of band A DNA. Untreated (control) sample of band B DNA was separated into two bands during its preparation or agar electrophoresis. The minor one corresponded to band A DNA. This result suggests that almost all band B DNA are converted to only band A (linear) DNAs by cleavage, and also band B DNAs has only one specific site for EcoRI.

EcoRI-digest of band A DNAs was separated into three or four fragments with a large quantity of undigested band A DNAs by agarose gel electrophoresis. This result suggests that the location of EcoRI-site on band A DNA may differ from molecule to molecule, and also the major part of band A DNA would not possess any EcoRI sites. From these results, it is considered that the conversion of band B DNA to band A DNA may be due to a specific or restricted cleavage and not by random cleavage. It is also supposed that the linear form of plasmid pSAl in plate culture is produced from its original closed-circular form via an intermediate, open-circular form. The main conversion should occur in vivo.

\section{Plasmid pSAl-free strain PKC}

To examine the existence of pSAl DNA in pock-cured strain PKC, DNA prepara-

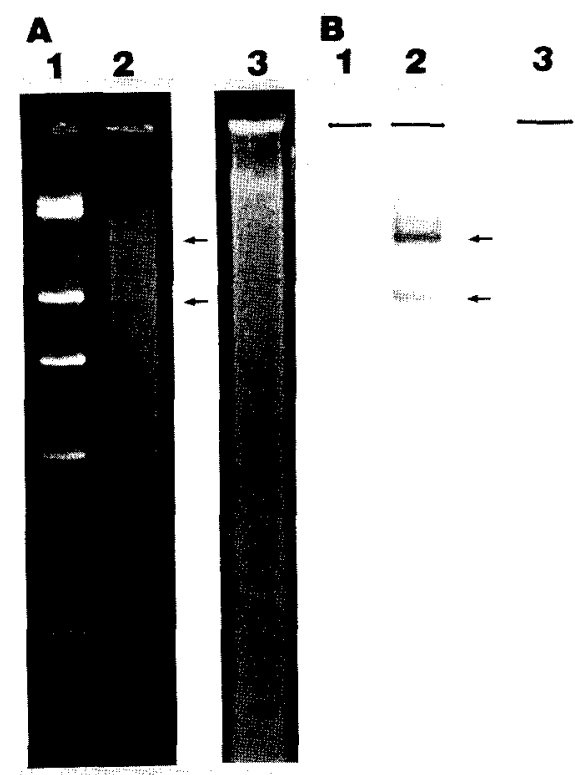

Fig. 7. Agarose gel electrophoresis and Southern blot analysis of DNAs from wildtype strain and strain PKC of Streptomyces azureus.

A, agarose gel electrophoresis; B, Southern blot analysis using band A DNA as a probe. Lane 1, HindIII-cleaved lambda DNA markers ; lane 2, wild-type strain DNA ; lane 3, strain PKC. 
Table 1. Presence and conformation of plasmid pSA1 in pock-forming Streptomyces azureus ATCC 14921 and its pock-cured derivative.

$\begin{array}{lll}\begin{array}{l}\text { Mycelia from } \\ \text { plate culture } \\ \text { of wild-type strain } \\ \begin{array}{c}\text { with overlapping pocks } \\ ++\end{array}\end{array} & \begin{array}{l}\text { Mycelia from } \\ \text { liquid culture } \\ \text { of wild-type } \\ \text { strain }\end{array} & \begin{array}{l}\text { Mycelia from } \\ \text { plate or liquid } \\ \text { culture of pock-cured } \\ \text { strain PKC } \\ \text { (and OC) }\end{array} \\ \end{array}$

+ , Presence ; -, Absence ; OC, Open-circular; CC, closed-circular

tion from strain PKC was applied to agarose gel electrophoresis together with DNA of wild-type strain. Then hybridization was carried out and radiolabeled band A DNA was used as a probe. As shown in Fig. 7, both bands (A and B) of wild-type strain hybridized very well with the probe. However, in the DNA preparation from strain PKC, there were no DNAs which hybridized with the probe band A DNA. This result indicates that pock-cured strain PKC has no plasmidpSAl and as such it is a plasmid pSAl-free strain. Table 1 summarized the presence and forms of plasmidpSAl in wild-type strain and strain PKC.

\section{Pock-forming activity of linear and circular form DNAs}

The pock-transforming activity of purified band A and band C DNAs was examined following the methods of protoplast transformation in the presence of PEG. About $1 \times 10^{7}$ protoplasts of strain PKC and $0.1 \mu \mathrm{g}$ of both DNAs were used. Pockforming transformants appeared at a low frequency with $\mathrm{pSAl}$ (approximately 1 to $5 \times$ $10^{3}$ pocks per $\mu \mathrm{g}$ of DNA), when they were plated together with strain PKC. Almost all colonies which were transformed continued to harbor the pock-forming activity even after several subculturing. This result indicates that linear and circular pSAl from a wild-type strain of S. azureus are associated with pock formation.

\section{ACKNOWLEDGEMENTS}

This work was supported by a Grant-in-Aid for Scientific Research from the Ministry of Education of Japan, the Takeda Science Foundation and the Sapporo Biological Science Foundation.

\section{REFERENCES}

Akagawa, H., K. Kawaguchi and M. Ichihara 1984 Plasmids of Streptomyces kasugaensis MB273: their pock formation, their dispensable endonuclease cleavage sits for pock formation and transformation of S. kasugaensis MB273 by them. J. Antibiot., $37: 10161025$

Bibb, M. J., R. F. Freeman and D. A. Hopwood 1977 Physical and genetical characterization of second sex factor, SCP2 for Streptomyces coelicolor A3 (2). Mol. Gen. Genet., 154: 155-166

Bibb, M. J. and D. A. Hopwood 1981 Genetic studies of the fertility plasmid SCP2 and its SCP2*. J. Gen. Microbiol., 126: 427-442

Chater, K. F., D. H. Hopwood, T. Kieser and C. J. Thompson 1982 Gene cloning in Streptomyces. Curr. Topics Microbiol.Immunol., $96: 69-95$

Kieser, T., D. H. Hopwood, H. M. Wright and C. J. Thompson 1982 pIJ101, a multi-copy broad 
host-range Streptomyces plasmid: functional analysis and development of DNA cloning vectors. Mol. Gen. Genet., 185: 223-238

Kobayashi, T., H. Shimotu, S. Horinouchi, T. Uozumi and T. Beppu 1984 Isolation and characterization of a pock-forming plasmidpTA4001 from Streptomyces lavendulae. J. Antibiot., $37: 368$ 375

Maniatis, S., E. F. Fritsch and J. Sambrook 1982 Molecular cloning : a laboratory manual. p. 92184, Cold Spring Harbor Laboratory, Cold Spring Harbor NY

Manis, J. J. and S. K. Highlander 1982 Partial characterization of a small, multi-copy plasmid from Streptomyces epinosus and the derivation of a high-copy number deletion mutant. Gene, 18 : 13 20

Miyoshi, Y. K., S. Ogata and S. Hayashida 1986 Multicopy derivative of pock-forming plasmid pSAl in Streptomyces azureus. J.Batercriol., 168: 452-454

Murakami, T., C. Nojiri, H. Toyama, E. Hayashi, Y. Yamada, and K. Nakaoka 1983 Pock forming plasmids from antibiotic-producing Streptomyces. J. Antibiot., $36: 429-434$

Ogata, S., Y. Koyama, Y. Sakaki and S. Hayashida 1983 Isolation of linear DNA associated with pock formation in Streptomyces azureus. Agric.Biol. Chem., 47 : 2127-2129

Ogata, S., Y. K. Miyoshi, and S. Hayashida 1985 Transfection and transformation systems for pock-forming and thiostrepton-producing Streptomyces azureus. J. Fac. Agr., Kyushu Univ., 29 : 179-188

Ogata, S., S. Yoshino, H. Suenaga, K. Aoyama, N. Kitajima and S. Hayashida 1981 Specific lysogenicity in Streptomyces azureus. Appl. Environ. Microbiol., 42 : 135-141

Omer, C. and S. N. Cohen, 1985 SLPl : transmissible Streptomyces chromosomal element capable of site-specific integration, excision, and autonomous replication, p 449-453. In L. Leive (ed.), Microbiology-1985. American Society for Microbiology, Washington, D. C. 